\title{
Neurosciences in byzantine era
}

Keywords: neurosciences, byzantium, neurophilosophy

\section{Editorial}

The history of Byzantium lasted thousand years, ${ }^{1}$ which were plenty of cultural and scientific contributions and achievements, which adorned the wide spectrum of World civilization. Medicine in Byzantium was connected tightly with Greek and Hellenistic philosophy and Christian spirituality offering precious scientific and humanitarian accomplishments.

Neurosciences and neurophilosophy in Byzantium were mostly based on Aristotelian, Neoplatonic and skeptical philosophical backgrounds, following also the long tradition of the ancient Greek and Hellenistic authorities in Neurology, Neuroanatomy, Neurophysiology and experimental Neurology. ${ }^{2,3}$ The relationship between soul and body was a crucial issue in Byzantine neurosciences, which considered, according to Aristotelian doctrines, that all the activities of the body were motivated by the soul. ${ }^{4}$ Aristotle considered that the wisdom would be the achievement of the harmonious homeostatic equilibrium between body and soul, resulting in interior peace and optima mental actualization. ${ }^{4}$

The Hippocratic manuscripts, which composed the extensive canon, ${ }^{5}$ in association with the detailed multi-dimensional Galen's dissertations ${ }^{6}$ have been accepted as the principal Handbooks in Medical Schools in Constantinople and the main "vade mecum" in practicing medicine for the physicians of the metropolitan Hospitals. The theories of Herophilus on the blood supply of the brain, the description of the stroke due to cardiac arrhythmias and the association of the high blood pressure with brain hemorrhages were highly respected by byzantine neurologists, who focus their diagnostic capacity on the meticulous physical examination of the patients. The knowledge of the Neuroanatomy and Neuropathology was based on the extensive research on that field by Erasistratus and Galen, who described the anatomy of the brain cortex, the cerebellum, the spinal cord as well as the interior structure of the brain, such as the hippocampus, the thalamus and the basal ganglia. ${ }^{3}$ The contributions of Soranus, who described paraplegia, vertigo and tetanus, and Areteus, who described the decussation of the corticospinal and spinothalamic tracts, in parallel way with the theories of Erasistratus on psychosomatic medicine and emotional disorders, helped in designing the scientific profile of the Neurosciences in Constantinople. ${ }^{7}$

The list of famous doctors, whose contribution in the field of neurosciences is much recognized, includes the following distinguished physicians and academic teachers:

i. Oribasius of Pergamos (325-403A.D), who was the personal physician to Emperor Julian the Apostate (361-363 A.D). He was appointed as professor of Medicine in Alexandria. During his long scientific carrier he published an encyclopedia of Medicine in seventy volumes, incorporating the corpus Hippocraticum, the works of Galen and many manuscripts of authors, who practiced Medicine in the Hellenistic period. He described many neurological issues, such as the function of memory, the dementia, the insomnia, the cephalalgia, the meningo-encephalitis and the traumatic lesions of the spinal cord. ${ }^{8}$

ii. Aetius of Amida (sixth century A.C.) was the first doctor who described the neurological complications of diphtheria. $\mathrm{He}$
Volume 8 Issue 4 - 2018

\author{
Stavros J Baloyannis \\ Research Institute for Alzheimer's disease, Aristotelian \\ University, Greece
}

Correspondence: Stavros J Baloyannis, Professor Emeritus, Aristotelian Univesity, Angelaki 5, Thessaloniki 5462I, Greece, Tel +302310270434, Fax+302310270434, Email sibh844@otenet.gr

Received: July 05, 2018 | Published: July 18, 2018

also published a Hand Book of Medicine composed of sixteen volumes, including therapeutics of mental disorders. His work was evaluated as the most comprehensive and useful contribution in the medical literature in Byzantium. ${ }^{9}$

iii. Alexander of Tralles (525-605) described the various forms of cephalalgia, many epileptic phenomena and several mental dysfunctions. His increased experience by visiting hospitals and infirmaries in various countries of the world, including Greece, Italy, Spain and Gaul enabled him to become an authority in Neurology and Neurosciences. He described mainly mental disorders, caused by starvation and neurotoxicity. He wrote many dissertations, expressing his personal view on the etiopathology of the diseases of the brain and spinal cord, arguing also some Galen's views and unproved speculations. His main offer as writer was a therapeutic syllabus, which described the current pharmaceutical and physical therapies of many serious diseases of internal medicine and neurology. His special interest for the disease of the eyes and the disorders of the vision resulted in writing a dissertation on the etiology and treatment of the ocular diseases, which may be assessed as the initial scientific approach to field of Ophthalmology. ${ }^{9}$

iv. Paulus of Aegina (625-690), was one of the most distinguished and highly esteemed physicians of Alexandria. He was in charge, as chief neurologist, of the seven hospitals of the city, which were founded by the saint Patriarch John the Merciful, the man of the real Christian love. Paulus must be considered as the first Child Neurologist, given that he accumulated substantial knowledge and important experience on new born and infant neurology, serving as chief neurologist in the |maternity hospitals of Alexandria. He was one of the first authors who described the most frequent congenital malformations of the brain and the spinal cord. He described also thoroughly the meningitis and the encephalitis, underlining their fatal prognosis or their serious consequences on the mental development of the child. ${ }^{10}$ It is worth to mention, that Paulus of Aegina, was the first who described dementia due to depression 
(Pseudoanoia), which might be reversed by treating depression primarily. His main contribution in medical bibliography was the

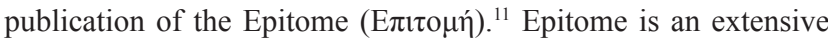
work, a real medical encyclopedia, including in the sixth chapter a substantial number of brain disorders, lesions of the peripheral nerves and some useful neurosurgical techniques. The impact of Epitome in the academic world was enormous, since it was used as essential medical text book for many centuries.

v. Theophilos Prorospatharios ( $9^{\text {th }}$ century) was a multi-dimensional and very gifted personality. He was protospatharios, famous physician, philosopher following the monastic life in advanced age. Theophilos was a very skilled neuro-anatomist, who published an excellent thesis entitled "On the structure of the Human body". He was also the author of some short treatises "on pulses', "on urine", "on secretions", "on the Hippocratic Aphorisms, ${ }^{12}$ " which contributed greatly in the perfection of medical education and practice. ${ }^{13}$ He believed deeply in the sacral character of the human life and the validity of the harmonious psychosomatic interactions.

vi. Theophanes "Nonnos" (10 $10^{\text {th }}$ century). was practicing medicine and neurology in Constantinople in the era of Macedonian Renascence. ${ }^{1}$ He became famous by his voluminous Handbook

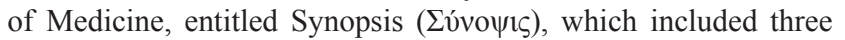
hundred chapters on internal medicine and neurology,one chapter on obstetrics and one on Pharmacology.

vii. Ioannis Zachariou, Actuarius, was one of the most eminent neurologists and psychiatrists in Constantinople. He was appointed as personal physician to Emperor Andronicos III and at the same time he was nominated Head of the department of Internal Medicine at the Xenon (Hospital) of Pantocrator and chief physician at the Hospital of Mangana, in the $14^{\text {th }}$ century. In his book entitled "On the function and the passions of the soul ${ }^{13}$ " he described the various properties and activities of the soul as well as the passions, which disturb the serenity of the mind.

viii. Nickolaos Myrepsos, Actuarius was one of the most distinguished doctors in Constantinople. He was reasonably appointed as personal physician to Emperor John III Vatatzis. His Textbook entitled Dynameron or Materia Medica was an extensive pharmacology, which included 2600 drugs and therapeutic substances. His contribution in the treatment of the neurological and mental diseases, exercised an enormous influence on the Arabic Medicine and Pharmacology.

The most advanced expression of medical care, associated with philanthropy and social welfare was the foundation of many hospitals in Constantinople $\mathrm{e}^{14}$ and in other major cities of Byzantine Empire, which were well organized, including among the others, units of Neurology and Psychiatry, ${ }^{15}$ intensive care units, outpatient clinics, Pharmacy, Library and Chapels. Among the therapeutic methods for the treatment of mental disease, the music therapy, the physical therapy and spiritual support were included and practiced daily. ${ }^{16}$ Some of the Hospitals were Teaching Hospitals, affiliated with the School of Medicine of the University of Constantinople, the famous Magnaura.

The greatest and highly respected Hospital in Constantinople

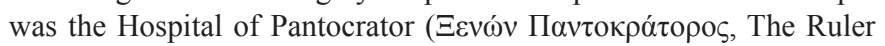
of All), founded by the Emperor John B' Comnenos and his wife Theodora in $1136 .{ }^{17}$ According to its foundation charter (typicon) the hospital was planned to cover all the special field of Medicine and Surgery and to offer the best didactic and research possibilities to medical students and young physicians. The hospital employed more than 50 physicians and a considerable number of nurses, physic therapists, pharmacists, dieticians, technicians, musicians, clergy men and administrators.

The doctors, who were elected for joining the staff of the hospital were the best of the Empire, with the highest credentials, the best reputation and long experience in practicing medicine. To be a member of the medical staff of the hospital of Pantocrator was the highest scientific distinction and public recognition for a physician in Constantinople at Byzantine era. Large number of Medical students participated in the daily activities of the hospital, attending the clinical examination of the patients, the diagnostic procedures, the prognostic evaluation and the therapeutic protocols, under the close supervision of the academic personnel of the hospital.

The head of each medical or surgical unit was a Professor of Medicine or Surgery respectively, with the title (officium) of Actuarius, who worked as full time doctor treating patients and teaching medical students, residents and young physicians. The hospital was equipped with an updated medical library, which was the richest in the Empire, including the entire Corpus Hippocraticum, all the dissertations by Galen, Erasistratus and Herophilos, manuscripts of Soranos and all the medical literature written by ancient Greek and Hellenistic authors of the famous schools of Alexandria, Cos, and Athens. The collection of the medical literature was gradually enlarged by the accumulation of writings of Byzantine doctors, who contributed greatly in the advancement of medical sciences. ${ }^{18}$

Even from the initial period of its function, the hospital of Pantocrator included departments of Neurology and Psychiatry, equipped with laboratories of Neuroanatomy and Neurophysiology, and units of mental improvement and speech therapy. On the top of the medical staff of the hospital was the personal physician to the Byzantine Emperor, the Lord (Archon) Actuarius, who officially performed as the General Director of the foundation. The Hospital of Pantocrator has been the paradigm and the model for the Hospitals of the Arabic World. ${ }^{19}$

Among the five wards of the Hospital of Pantocrator the fourth and the fifth provided service to neurological and psychiatric patients, having in charge two doctors called protominite ( $\pi \rho \omega \tau$ ○ were well trained in Neurology and Psychiatry according to foundation charter (typicon) of the Hospital. ${ }^{20}$ The two wards of Obstetrics and Gynecology employed exclusively female nursing personnel and a female physician (doctoress, ió $\tau \rho \alpha \imath \alpha$ ) was in charge, assisted by a considerable number of trainees and midwifes. In the therapeutic protocols, which were addressed to those patients, who suffered from brain and mental disorders, the utilization of frequent baths and the administration of vegetarian diet played an important beneficial role, in association with the psychotherapy and the music therapy.

The training in Neurology in the Hospital of Pantocrator was primarily based on the detailed physical examination of the patients, the evaluation of the symptoms, the mental condition, the behavior, the speech capacity of the patients, and the correlation of each case with relevant ones, which were previously described in medical textbooks by eminent authors. The profound erudition, the gentle competition, the search for new therapeutic horizons and the high moral standards shaped the ideal atmosphere of the medical studies in Constantinople in Byzantine Era, which became a bright paradigm of medical education for the Arabian Medicine ${ }^{21}$ and the Western World. ${ }^{22}$ 
It is important that the neurological units and mental institutions in the Byzantine Era irradiated all over the world the spirit of devotion, compassion, charity, mercy, respect, brotherly love and self sacrifice for the suffering human being.

\section{Acknowledgements}

None.

\section{Conflict of interest}

The author declares no conflict of interest.

\section{References}

1. Browning Robert the byzantine empire. London: Weidenfeld and Nicolson; 1980.

2. Baloyannis SJ. The Neurosciences in the Greek World. In KK. Sinha et al. editors. Some aspects of history of Neurosciences. Ranchi: Catholic Press; 2003. p. 97-117.

3. Baloyannis SJ. The Neurosciences in Hellenistic Alexandria: an harmonization of philosophy and medicine. In KK. Sinha et al. editors. Some aspects of history of Neurosciences. Ranchi: Catholic Press; 2004. p. $85-110$.

4. Aristotle De anima. Greek text and English transl. In: WS Hett, et al. editors. Cambridge MA Harvard University Press; 1957.

5. Hippocrates Oeuvre completes; traduction nouvelle avec le text grec. In: E Littré, editor. Paris: 10 vols Baillière; 1839-1891.

6. Galen Opera Omnia. Volumes 22. In: DCG Kuhen, editor. Gnobloch. Leipzig; 1821-1833.

7. Francis Adams. Aretäus Cappadocius The extant works. London: The Sydenham Society; 1846. 63 p.

8. Bloch Iwan Byzantinische Medizi. Handbuch der Geschichte der Medizin. Max Neuburger und Julius Pagel, Vol. 2 Jena: G Fischer; 1902;1:492-588.
9. Photios Bibliotheca René Henry. 8 Vol Paris: "Les Belles Lettres"; 1959;77(3):152.

10. Paulus of Aegina The seven books of Paulus of Aegina. English tranl. London: Francis Adams The Sydenham Society; 1844-1847. 2008. 540 p.

11. Hunger herbert die hochsprachliche profane literatur der byzantiner. 2 Vol. Handbuch der Altertumswissenschaft. Munich: Beck; 1978;2:299.

12. Hippocrates Aphorismi Hippocratus (Hippocrates'Aphorisms). Amsterdam: Hendrik Wetstein; 1685.

13. Wilson NG. Scholars of Byzantium. London and Baltimore: Duckworth and Johns Hopkins University Press; 1983. 283 p.

14. Constantelos D. Byzantine Philanthropy and Social Welfare. New Brunswick, NJ: Rutgers University Press; 1968. 356 p.

15. Horden P. How Medicalised Were Byzantine Hospitals? Medicina e Storia. 2006;10:45-74

16. Androutsos G, Karamanou M, Matsaggas A. The hospital institutions of Byzantium and the hospital (xenon) of pantokrator monastery in constantinople. Presse Med. 2012;41(1):68-73.

17. Miller T. The birth of the Hospital in the Byzantine Empire. Baltimore and London: John Hopkins University Press; 1997.

18. Miller TS. Byzantine Physicians and their Hospitals. Medicina nei Secoli Arte e Scienza. 1999;11(2):323-335.

19. Gutas Dmitri Greek Thought, Arab Culture. The Graeco-Arabic Translation Movement in Baghdad and Early 'Abbasid Society (2nd4th/8th-10th Centuries). London and New York: Routledge; 2000.

20. Gautier Paul. Le typikon du christ sauveur pantocrator. REB. 1974;32:1145.

21. Angeletti LR, Cavarra B. Influenze Byzantine nelle strutture sanitarie dei secoli V-IX in Roma. Medicina nei Secoli Arte e Scienza. 1993;2:279297.

22. Baloyannis SJ. Avicenna: The mysticism of the Greek medicine in the Arabian world. Encephalos. 1997;34:11-29. 